\title{
Experimental Study of Non-English Major Freshmen's Inquiry Cooperative \\ Learning in Jiujiang University
}

\author{
Wang Yuanfen \\ Jiujiang University Jiujiang, Jiangxi China 332005
}

\begin{abstract}
In order to improve students' English ability of communication and creativity, strengthen the spirit of unity and coordination, according to the characteristics of English subject, concludes "inquiry cooperative learning" model of classroom teaching. The key points are: Inquiry practice is the main line, teachers' guide the way, assistance with students' discussing cooperatively, fully reflects the principles of universality, subjectivity and fundamental characteristic in the quality education. We took 90 freshmen in Jiujiang University as experimental subjects, of which 45 were in autonomic classes, the other 45 students in traditional classes. Through the teaching experiments, the students in autonomic classes through their own practice and exploration activities in the teacher's guidance and assistance, accessing to knowledge, not only does not affect the results of the English level test, but also form ability, cultivating sound character and lying a solid foundation for lifelong learning for the future development, achieving the common purpose of self-learning ability, English language ability and improving communicative competence.
\end{abstract}

Keywords: inquiry cooperative learning, freshmen, English learning, autonomy.

\section{Introduction}

Social development and technological progress require the learner to have the concept of lifelong learning and independent learning skills. In the field of higher education, how to keep students learning actively and make full use of resources in and out of classroom to develop their own autonomic learning ability has been need to be solved. From actual teaching we found a lot of university students harvest little in English after a few years' learning, many graduates are not good at applying knowledge to a new environment at work, and others are not good at teamwork. University teachers should reflect on it. Looking at English teaching in recent years, can be found English got a lot of people's attention. However, the traditional teacher-based classroom teaching model has been a prominent issue that restrains students' autonomy. As a result of the traditional evaluation system based on the examination as the only means, do not care about the students interests and different learning styles and treat each student simply, resulting in active learning is not high. Compared to the English level in secondary schools, some university students' English ability did not increase or even reversed. Teaching English in order to foster the autonomy in student learning, not only to impart knowledge but also enhance their self-confidence to learn. In view of this, improving the overall learning ability of students from the learning strategies is a viable thing.

In recent years, a large number of researches in the field of English teaching have revealed the importance of classroom interaction fully. In fact, 
the primary task in English learning is to "study" rather than "taught". The teaching performance should be based on the students' learning outcomes, and learning outcomes depend largely on the student's initiative and participation. How to motivate students to maximize the initiative and participation, the author's teaching practice over a long period, and draws on the theory of famous domestic and foreign experience, introduces "inquiry cooperative approach" especially .Cooperative approach focuses on groups, organizes teaching activities around learning-centered, emphasizes learners' self-directed, personal development and the intrinsic sense of motivation and cooperation. Partners must adhere to certain principles of cooperation between each other: cooperation between the parties in order to achieve a common goal or to carry out their mutually beneficial co-ordination between various parties.

\section{The experiment of inquiry cooperation learning}

\subsection{Experimental processes}

This experiment from September in 2013 to February of 2014 lasted half a year. Specific practices are as follows:

At the beginning of a new semester, we designed a questionnaire to investigate students' meta-cognitive strategy that they have known. We signed contracts for activities of self-study with students, the second week to prepare for the establishment of students' self-study file. In the process teacher help students set up learning English long-term and short-term goals, including the term goals, month goals and week goals, so as to formulate a feasible study plan. In order to enable students to learn opportunities of choosing learning methods and access to their own decision, teachers in the organization of activities in and outside class allow students have more choice as much as possible. For example: every 10 minutes before class let students to carry out their own arrangements of English language activities as they like, including news, small lectures, storytelling, short speech, and sing songs in English, the formation is limitless and to their own choice; students can organize the whole class together. In addition, the essay questions are quite general and so the range of options. The main form of monitoring the learning process is training students to write learning diaries, records of reflecting the feelings on their own experience of the methods of teaching and learning activities, so they can promote the progress of learning. In addition to assessment of teachers, students check homework between each other also urged to learn from each other, and make common progress, is an effective way to assess the purpose.

In addition, I also intend to use traditional teaching methods to teach the first and second units. Starting from the third unit changing teaching methods, such as the use of the form of drama in unit three; the fourth unit I use the form of debate; in fifth unit using the game "guess what", in unit six use the form of story-telling; seventh unit invited foreign guest teachers to give lectures. Feedback from students in the end of this semester, the students almost unanimously said that before and after the contrast they like student-centered teaching model much more. In view of this, encouraging independent learning, taking communicative teaching methods meet the current reality of students and welcomed by them.

\subsection{Implications for language teaching}

One-semester teaching experiment shows: 1) autonomous classroom activities enable students to change their ideas and attitudes, gradually build on and adapt to self-learning mode, forming 
self-study habits; 2) experimental group's students through cultivating and training, can let students to learn and manage their own learning methods, in order to monitor their own learning process effectively, take responsibility for their own learning; 3) autonomic classroom activities enhance the effect of listening and speaking abilities of students obviously, plays a positive effect to the improvement of comprehensive ability, which is exactly in line with university English course requirements "enhancing the overall capacity, listening and speaking abilities leading"; 4) autonomic classroom model not only affect the National College English Exam Band 3 test scores, their pass rates of the experimental group was also higher than the traditional classroom model of the comparison group (above $22 \%$ ), This shows that the output-based classroom activities will not affect the answer questions capabilities in the input-type examination; 5) language is learned, not taught. Although the traditional classroom is teaching language-based, but students still can not completely control the content that being taught; while the autonomic classroom model teachers taught very few in language, but students still can acquire the language knowledge, especially the ability to receive information and obtain a higher test scores, it is worth pondering, and is precisely embodied the constructivism-based self-learning.

\section{Conclusions}

The new curriculum standards pointed out that for all students, for students' all-round development and lay the foundation of life-long development is the core idea of teaching reform. To focus on cultivating students the ability of comprehensive use of English language, stimulate and foster students' interest in learning English, establish self-confidence, develop good study habits, create an effective learning strategy, put developing self-learning ability and the spirit of cooperation in the first place. Wanting to implement, we must find a people-oriented, able to embody the values of language courses, matching the concept in the new curriculum standards, advanced and efficient way to achieve the diversity of learning styles, that is, to highlight the dominant position of students, provide students with the larger space for practice, play their initiative and creativity, through exchanging ideas to cultivate communicative competence, lay the foundation for lifelong learning and development. Inquiry cooperative learning not only can cultivate students self-learning ability, but also stimulate learning motivation, eliminate loneliness, enhancing the students' ability to communicate between individuals, is very important for students to cultivate creative ability, difference of thinking, and the spirit of exploration.

Cultivating students' self-study foreign language ability is a long-term complex process, continuous learning through training and accessing to the summary, it requires teachers to guide students and trust students, more importantly, students will have the tenacity to learn and to overcome difficulties, having the spirit of study hard, needed to give a good learning environment to have sufficient time for self-study at the same time, so that students can be truly cultivated the ability of independent learning.

\section{References}

[1] Corder S. P. Introduction to Applied Linguistics $[\mathrm{M}]$. Penguin: Haronds worth, 1973.

[2] Holec, H. Autonomy and Foreign Language Learning [M].Oxford: Pergamon Press, 1981. 
[3] Jacobs M.George and Jessica Ball "An investigation of the structure of group activities in EFL course books" EFL Journal 1996.

[4] Krashen S. \& Terrell T. The Natural Approach [M]. Pergamon, New York, 1983.

[5] Little, D. Learner Autonomy: Definition, Issues and Problems [M]. Dublin: Authentic, 1991.
[6] McLaughlin B. Theories of Second Language Learning $[\mathrm{M}]$. New York: Edward Arnold, 1987.

[7] Swain, M. Communicative competence: Some roles of comprehensible input and comprehensible output in its development [C] // Gass \& C. Madden. Input in Second Language Acquisition. Rowley, Mass.: Newbury House, 1985: 235-253. 